\title{
EKSPERIMENTASI MODEL PEMBELAJARAN \\ KOOPERATIF TIPE TEAM ASSISTED INDIVIDUALIZATION (TAI), GROUP INVESTIGATION (GI), DAN PEMBELAJARAN LANGSUNG PADA MATERI PERSAMAAN GARIS LURUS DITINJAU DARI KEMANDIRIAN BELAJAR SISWA KELAS VIII SMP NEGERI SE-KOTA SURAKARTA TAHUN PELAJARAN 2015/2016
}

\author{
Venty Meilasari ${ }^{1}$, Budiyono $^{2}$, Isnandar Slamet ${ }^{3}$ \\ 1,2,3 Prodi Magister Pendidikan Matematika, FKIP Universitas Sebelas Maret Surakarta
}

\begin{abstract}
This research aimed to find out: (1) which one providing better mathematics learning achievement, TAI model, GI model or direct instruction model, (2) which one providing better mathematics learning achievement, the high, medium or low independence of learning students, (3) in each learning models, which one providing better mathematics learning achievement, the high, medium, or low independence of learning students, (4) in each categories of independence of learning, which one providing better mathematics learning achievement, TAI model, GI model or direct instruction learning model. This research used the quasi-experimental research method. The research design was a $3 \times 3$ factorial design. The population were all students of the eight class of junior high school in Surakarta on academic year 2015/2016. The sample was taken using stratified cluster random sampling and consisted of 281 students. The instruments used were independence of learning questionnaire and mathematics achievement test. The proposed hypothesis of the research were analyzed by using two-way analysis of variance with unbalanced cells. The conclusions of this research were as follow. (1) TAI model provided the mathematics achievement as good as GI model, TAI model and GI model provided better mathematics achievement than direct instruction model. (2) The high independence of learning student had better mathematics achievement than medium and low independence of learning students, and the medium had better than low independence of learning students. (3) In TAI model and direct instruction model, the high, medium, and low independence of learning had the same mathematics achievement, in GI learning model, the high independence of learning students had mathematics achievement as good as the medium independence of learning students, the high independence of learning had better than the low independence of learning, and the medium independence of learning students had the same as the low independence of learning students. (4) In high and low independence of learning, TAI model, GI model, and direct instruction model provided the same achievement, in medium independence of learning, TAI model and GI model provided the same achievement, TAI model provided better achievement than direct instruction model, GI model was the same as direct instruction model.
\end{abstract}

Keyword: TAI, GI, Direct Instruction, Independence of Learning, and Mathematics Achievement

\section{PENDAHULUAN}

Pendidikan merupakan bagian integral pembangunan dan kemajuan suatu bangsa.

Pendidikan diharapkan dapat mempersiapkan siswa untuk dapat hidup pada masa sekarang dan masa mendatang. Oleh karena itu, inovasi di bidang pendidikan sangat perlu dilakukan untuk meningkatkan kualitas pendidikan sehingga dapat menghasilkan output yang kompeten sesuai tuntutan zaman. 
Salah satu inovasi di bidang pendidikan adalah inovasi dalam pembelajaran matematika. Mata pelajaran matematika adalah salah satu mata pelajaran yang diselenggarakan di sekolah sejak pendidikan dasar sampai pendidikan tinggi. Meskipun demikian, prestasi belajar matematika siswa masih rendah.

Hasil penelitian Programme of Internasional Student Assesment (PISA) tahun 2012 menunjukkan bahwa Indonesia menempati peringkat ke-64 dari 65 negara peserta pada kategori mathematics literacy. Selain itu, menurut penelitian Trends in International Mathematics and Science Study (TIMSS) pada tahun 2011, Indonesia berada pada peringkat ke-38 dari 42 negara peserta. Hal ini menunjukkan bahwa prestasi belajar matematika siswa Indonesia masih rendah jika dibandingkan dengan Negara- Negara lain. Selanjutnya dalam ruang lingkup yang lebih sempit, hasil ujian nasional (UN) SMP tahun 2014 pada program PAMER UN menunjukkan bahwa matematika menduduki peringkat terbawah dibandingkan tiga mata pelajaran yang lain, yaitu hanya mencapai rerata nilai 6,89. Lebih mengerucut lagi, prestasi belajar matematika siswa SMP negeri di kota Surakarta hanya mencapai rerata nilai 6,40. Hal ini mengindikasikan bahwa banyak indikator pembelajaran yang memiliki daya serap rendah. Salah satu indikator yang memiliki daya serap rendah adalah materi persamaan garis lurus yang hanya mencapai 45,07\% untuk tingkat kabupaten/kota. Pencapaian yang rendah jika dibandingkan dengan daya serap untuk tingkat nasional yang mencapai 53,58\%. Rendahnya daya serap yang dicapai siswa pada materi persamaan garis lurus mengindikasikan bahwa belum berhasilnya proses pembelajaran yang telah dilalui siswa. Keberhasilan suatu proses pembelajaran dipengaruhi oleh faktor eksternal dan faktor internal.

Adapun salah satu faktor eksternal yang diduga menjadi penyebab utama adalah model pembelajaran yang masih berpusat pada guru. Pada umumnya guru masih menggunakan model pembelajaran langsung yang hanya mentransfer pengetahuan kepada siswa. Hal ini membuat siswa menjadi bosan dan tidak tertarik untuk mempelajari materi pelajaran khususnya persamaan garis lurus. Oleh karena itu, dibutuhkan model pembelajaran yang tepat agar dapat menghasilkan prestasi belajar yang lebih baik. Adapun materi pelajaran ini dipelajari oleh siswa kelas VIII yang berada dalam tahap perkembangan operasional formal. Menurut Andrich dan Styles (dalam Slavin, 2008:113) dalam tahap ini siswa lebih nyaman untuk belajar dengan teman sebayanya.

Salah satu model pembelajaran yang dapat memfasilitasi siswa untuk belajar dengan teman sebayanya adalah model pembelajaran kooperatif. Model pembelajaran ini menekankan pentingnya siswa membangun sendiri pengetahuan mereka melalui keterlibatan aktif siswa dan kerjasama antar siswa dalam proses belajar mengajar. Proses belajar mengajar lebih berpusat pada siswa. Menurut Jebson, SR. (2012) model 
pembelajaran kooperatif menghasilkan pencapaian yang lebih baik pada bidang matematika daripada model pembelajaran konvensional. Hal senada juga diungkapkan oleh Awovala dan Nneji (2012:7) yang menyatakan bahwa:

The result showed that significant difference existed in the mathematics achievement of cooperative and individualistic goal structure groups in favour of cooperative group. The cooperative strategy also enhanced student mastery of mathematics content at both the comprehension and application levels than at knowledge level cognition.

Hal ini berarti bahwa ada perbedaan yang signifikan pada prestasi belajar matematika siswa dengan struktur kooperatif dan individualistik. Jadi, dapat disimpulkan bahwa pembelajaran kooperatif memberikan hasil yang lebih baik daripada pembelajaran langsung. Slavin (2005: 26) menyatakan bahwa terdapat banyak tipe pembelajaran kooperatif. Tipe-tipe pembelajaran kooperatif dikategorisasikan menurut enam karakterisitik yaitu: tujuan kelompok, tanggung jawab individual, kesempatan sukses yang sama, kompetisi tim, spesialisiasi tugas, dan adaptasi terhadap kebutuhan kelompok. Diantara tipe dari model pembelajaran kooperatif adalah tipe Team Assisted Individualization (TAI) dan Group Investigation (GI).

Model pembelajaran kooperatif tipe TAI merupakan model pembelajaran yang menggabungkan teknik pembelajaran tertentu untuk mengatasi permasalahan pembelajaran individual dan meningkatkan ketrampilan kooperatif siswa. Pada pembelajaran ini siswa belajar dalam kelompok heterogen yang terdiri dari empat sampai lima orang. Dalam kelompok, siswa tidak hanya bertanggung jawab atas keberhasilan individu tapi juga keberhasilan kelompok sehingga diharapkan siswa untuk saling membantu dalam memahami materi pelajaran agar tercapainya prestasi kelompok yang maksimal. Hal ini didukung oleh hasil penelitian Avowala et al. (2013:6) yang menyatakan bahwa:

The results indicate that students' academic achievement was greatly improved when they were exposed to the teaching strategies of framing and team assisted individualized when compared with the conventional teaching method. Team assisted individualized strategy was found to be more effective because students had the opportunity to work together in teams, share views and opinions, and engage in brainstorming on problems.

Pernyataan tersebut bermakna bahwa TAI memberikan prestasi belajar yang lebih baik daripada model konvensional. TAI lebih efektif karena siswa mempunyai kesempatan untuk belajar bersama dalam tim, dapat berbagi pengetahuan dan pendapat, dan terlibat secara aktif dalam mendiskusikan permasalahan.

Model pembelajaran kooperatif tipe GI sebagai salah satu model pembelajaran kooperatif yang melibatkan siswa untuk mandiri sejak dari perencanaan, baik dalam cara untuk mempelajarinya melalui investigasi. Model ini merupakan model pembelajaran 
dimana siswa mengkonstruksi sendiri pengetahuannya terhadap suatu konsep. Dalam kelompok, siswa harus dapat berpikir secara kritis, analitis, tepat, dan bertindak kreatif untuk mendesain suatu penemuan. Hal ini menjadikan pengetahuan yang diperoleh menjadi lebih bermakna dan bertahan lama dalam memori siswa sehingga diharapkan dapat meningkatkan prestasi belajar siswa. Menurut Mitchell et al. (2008:394) "group investigation has potenstial to be a powerful form of cooperative learning". Hal ini sejalan dengan hasil penelitian Laila Fitriana (2010) yang menyimpulkan bahwa prestasi belajar matematika dengan pembelajaran kooperatif tipe GI lebih baik dibandingkan dengan pembelajaran langsung.

Salah satu faktor internal siswa yang mempengaruhi prestasi belajar adalah kemandirian belajar. Menurut Pintrich (dalam Torrano dan Carmen, 2004: 4) menyatakan ada empat fase untuk melihat tingkat kemandirian siswa, yaitu: perencanaan (planning), monitoring diri (self-monitoring), kontrol (control), dan evaluasi (evaluation). Siswa yang memiliki kemandirian belajar mampu membuat perencanaan dalam belajarnya, memonitoring diri, mengontrol diri serta mengevaluasi hasil belajar yang telah dicapainya. Siswa yang memiliki kemandirian belajar memiliki kombinasi keterampilan akademik dan pengendalian diri yang membuat pembelajarannya terasa lebih mudah sehingga menghasilkan prestasi belajar yang maksimal. Hal itu sesuai dengan penelitian yang telah dilakukan oleh Purna Bayu Nugroho (2014) yang menyatakan bahwa siswa dengan tingkat kemandirian belajar tinggi memiliki prestasi belajar yang lebih baik dari siswa dengan kemandirian sedang dan rendah, siswa dengan tingkat kemandirian sedang memiliki prestasi belajar yang lebih baik daripada siswa dengan tingkat kemandirian belajar rendah.

Tujuan dari penelitian ini adalah untuk mengetahui: (1) model yang menghasilkan prestasi belajar lebih baik, model pembelajaran kooperatif tipe TAI, GI, atau model pembelajaran langsung, (2) prestasi belajar lebih baik, siswa dengan kemandirian belajar tinggi, sedang, atau rendah, (3) pada masing-masing model pembelajaran, manakah yang memiliki prestasi belajar matematika lebih baik, siswa dengan kemandirian belajar tinggi, sedang atau rendah, (4) pada masing-masing kategori kemandirian belajar, manakah yang memiliki prestasi belajar matematika lebih baik, siswa yang diberi pembelajaran dengan menggunakan model pembelajaran kooperatif tipe TAI, GI atau model pembelajaran langsung.

\section{METODE PENELITIAN}

Penelitian ini merupakan penelian eksperimental semu dengan desain penelitian faktorial $3 \times 3$. Populasi dalam penelitian ini adalah seluruh siswa kelas VIII SMP Negeri 
se-Kota Surakarta tahun pelajaran 2015/2016 yang menggunakan kurikulum 2006. Di kota Surakarta terdapat 24 SMP Negeri yang masih menggunakan kurikulum 2006. Adapun sampel yang terpilih dalam penelitian adalah SMP Negeri 6 Surakarta kelas VIII C, VIII D, dan VIII E, SMP Negeri 11 Surakarta kelas VIII A, VIII B, VIII F, dan SMP Negeri 13 Surakarta kelas VIII E, VIII F, dan VIII G. Adapun teknik pengambilan sampel yang digunakan adalah stratified cluster random sampling.

Teknik Pengumpulan data meliputi metode dokumentasi yang mengumpulkan data kemampuan awal siswa, metode tes yang mengumpulkan data prestasi belajar, dan metode angket yang mengumpulkan data kemandirian belajar. Instrumen penelitian berupa tes prestasi belajar dan angket kemandirian belajar. Teknik analisis data menggunakan analisis variansi dua jalan dengan sel tak sama. Namun sebelumnya dilakukan terlebih dahulu uji prasyarat analisis yaitu uji normalitas dengan metode Lilliefors dan homogenitas dengan metode Bartlett. Selanjutnya digunakan uji Scheffe' untuk uji lanjut pasca anava.

\section{HASIL PENELITIAN DAN PEMBAHASAN}

Hasil uji prasyarat menyimpulkan bahwa semua sampel berasal dari populasi yang berdistribusi normal dan homogen. Selanjutnya berdasarkan uji keseimbangan disimpulkan bahwa ketiga kelompok belajar, yaitu TAI, GI, dan pembelajaran langsung dalam keadaan seimbang. Berikut rerata prestasi belajar matematika siswa disajikan pada Tabel 1 berikut.

Tabel 1 Rangkuman Rerata Marginal pada Masing-Masing Sel

\begin{tabular}{ccccc}
\hline \multirow{2}{*}{ Model Pembelajaran } & \multicolumn{3}{c}{ Kemandirian Belajar } & Rerata \\
\cline { 2 - 4 } & $\begin{array}{c}\text { tinggi } \\
\left(\mathrm{b}_{1}\right)\end{array}$ & sedang $\left(\mathrm{b}_{2}\right)$ & rendah $\left(\mathrm{b}_{3}\right)$ & Marginal \\
\hline Tai $\left(a_{1}\right)$ & 71,7241 & 70,2632 & 59,8184 & 67,7128 \\
$\operatorname{Gi}\left(a_{2}\right)$ & 75 & 66,4444 & 57,6923 & 66,1170 \\
Langsung $\left(a_{3}\right)$ & 66,0938 & 57,1875 & 60 & 61,1290 \\
\hline Rerata Marginal & 70,4762 & 65,1304 & 59,2073 &
\end{tabular}

Selanjutnya dilakukan uji hipotesis dengan menggunakan anava dua jalan dengan sel tak sama. Rangkuman anava dua jalan dengan sel tak sama disajikan pada Tabel 2 berikut.

Tabel 2 Rangkuman Anava Dua Jalan dengan Sel Tak Sama

\begin{tabular}{ccccccc}
\hline Sumber & JK & $\mathrm{dk}$ & $\mathrm{RK}$ & $\mathrm{F}_{\text {obs }}$ & $\mathrm{F}_{\alpha}$ & Kep \\
\hline A & 2011,9159 & 2 & 1005,9580 & 5,6172 & 3,029 & $\mathrm{H}_{\text {OA }}$ ditolak \\
B & 6266,2572 & 2 & 3133,1286 & 17,4951 & 3,029 & $\mathrm{H}_{\text {OB }}$ ditolak
\end{tabular}




\begin{tabular}{ccccccc}
$\mathrm{AB}$ & 2030,4735 & 4 & 507,6184 & 2,8345 & 2,405 & $\mathrm{H}_{\mathrm{OAB}}$ ditolak \\
Galat & 48711,4789 & 272 & 179,0863 & - & - & - \\
\hline Total & 59020,1255 & 280 & - & - & - & - \\
\hline
\end{tabular}

Berdasarkan Tabel 2 tersebut diperoleh hasil analisis variansi dua jalan dengan sel tak sama dengan saraf signifikan 0,05 . (1) $H_{0 \mathrm{~A}}$ ditolak sehingga terdapat perbedaan prestasi belajar pada siswa yang diberi perlakuan model pembelajaran kooperatif tipe TAI, GI, dan pembelajaran langsung. (2) $H_{\mathrm{OB}}$ ditolak sehingga terdapat perbedaan prestasi belajar antara siswa dengan kemandirian belajar tinggi, sedang, dan rendah. (3) $H_{\mathrm{OAB}}$ ditolak sehingga terdapat interaksi antar model pembelajaran dan kemandirian belajar terhadap prestasi belajar matematika.

Setelah diperoleh bahwa $\mathrm{H}_{0 \mathrm{~A}}$ ditolak, selanjutnya dilakukan uji komparasi ganda antar baris. Hasil uji komparasi ganda antar baris disajikan pada Tabel 3 berikut.

Tabel 3 Hasil Uji Komparasi Rerata Antar Baris

\begin{tabular}{ccccc}
\hline No & $\mathrm{H}_{0}$ & $\mathrm{~F}_{\mathrm{obs}}$ & $2 \mathrm{~F}_{(0,05 ; 2 ; 272)}$ & Keputusan Uji \\
\hline 1 & $\mu_{1-}=\mu_{2^{-}}$ & 0,6683 & 6,058 & $\mathrm{H}_{0}$ diterima \\
2 & $\mu_{2^{*}}=\mu_{3^{-}}$ & 6,5289 & 6,058 & $\mathrm{H}_{0}$ ditolak \\
3 & $\mu_{1-}=\mu_{3^{-}}$ & 11,3745 & 6,058 & $\mathrm{H}_{0}$ ditolak \\
\hline
\end{tabular}

Berdasarkan Tabel 3, diperoleh simpulan sebagai berikut: (1) hipotesis pertama diterima, hal ini berarti bahwa prestasi belajar matematika siswa dengan model pembelajaran TAI sama baiknya dengan prestasi siswa dengan model pembelajaran GI, (2) hipotesis kedua ditolak, hal ini berarti terdapat perbedaan prestasi belajar matematika siswa yang diberi model pembelajaran GI dan pembelajaran langsung, berdasarkan rerata marginalnya prestasi belajar siswa yang diberi model pembelajaran GI lebih baik daripada yang diberi model pembelajaran langsung, (3) hipotesis ketiga ditolak, hal ini berarti terdapat perbedaan prestasi belajar antara siswa yang diberi model pembelajaran TAI dan pembelajaran langsung, berdasarkan rerata marginalnya diketahui bahwa prestasi belajar matematika siswa yang diberi model pembelajaran TAI lebih baik daripada yang diberi pembelajaran langsung.

Hasil penelitian ini sesuai dengan penelitian yang dilakukan oleh Triana Harmini (2014) yang menyatakan bahwa prestasi belajar matematika siswa yang diberi model pembelajaran TAI sama baiknya dengan prestasi belajar matematika siswa yang diberi model pembelajaran GI dan prestasi belajar matematika siswa yang diberi model pembelajaran TAI dan GI lebih baik daripada prestasi belajar matematika siswa yang diberi pembelajaran langsung. 
Karena $\mathrm{H}_{0 \mathrm{~B}}$ ditolak, maka dilanjutkan dengan uji komparasi ganda antar kolom. Adapun hasilnya disajikan pada Tabel 4 berikut.

Tabel 4 Hasil Uji Komparasi Rerata Antar Kolom

\begin{tabular}{ccccc}
\hline No & $\mathrm{H}_{0}$ & $\mathrm{~F}_{\mathrm{obs}}$ & $2 \mathrm{~F}_{(0,05 ; 2 ; 272)}$ & Keputusan Uji \\
\hline 1 & $\mu_{1}=\mu_{2}$ & 7,7460 & 6,058 & $\mathrm{H}_{0}$ ditolak \\
2 & $\mu_{-2}=\mu_{3}$ & 9,3774 & 6,058 & $\mathrm{H}_{0}$ ditolak \\
3 & $\mu_{-1}=\mu_{3}$ & 29,4228 & 6,058 & $\mathrm{H}_{0}$ ditolak \\
\hline
\end{tabular}

Berdasarkan Tabel 4 dapat disimpulkan bahwa: (1) hipotesis pertama ditolak, berarti terdapat perbedaan prestasi belajar matematika antara siswa berkemandirian tinggi dan sedang. Berdasarkan rerata marginal prestasi belajar siswa dengan kemandirian belajar tinggi lebih baik daripada siswa dengan kemandirian belajar sedang, (2) hipotesis kedua ditolak, berarti terdapat perbedaan prestasi belajar antara siswa berkemandirian belajar sedang dan rendah. Berdasarkan rerata marginal, prestasi belajar siswa berkemandirian belajar sedang lebih baik daripada siswa berkemandirian belajar rendah, (3) hipotesis ketiga ditolak, berarti terdapat perbedaan prestasi belajar antara siswa berkemandirian belajar tinggi dan rendah. Berdasarkan rerata marginal prestasi belajar siswa berkemandirian belajar tinggi lebih baik daripada siswa berkemandirian belajar rendah. Hasil penelitian ini sejalan dengan penelitian yang dilakukan oleh Purna Bayu Nugroho (2014) yang menyatakan siswa dengan kemandirian belajar tinggi mempunyai prestasi belajar matematika yang lebih baik daripada siswa dengan kemandirian belajar sedang dan rendah. Siswa dengan kemandirian belajar sedang memiliki prestasi belajar matematika yang lebih baik daripada siswa dengan kemandirian belajar rendah.

Selanjutnya dilakukan uji komparasi ganda antar sel yang disajikan pada Tabel 5

Tabel 5 Hasil Uji Komparasi Rerata Antar Sel

\begin{tabular}{ccccc}
\hline No & $\mathrm{H}_{0}$ & $\mathrm{~F}_{\mathrm{obs}}$ & $8 \mathrm{~F}_{(0,05 ; 8 ; 272)}$ & Keputusan Uji \\
\hline 1 & $\mu_{11}=\mu_{12}$ & 0,1960 & 15,784 & $\mathrm{H}_{0}$ diterima \\
2 & $\mu_{11}=\mu_{13}$ & 11,0735 & 15,784 & $\mathrm{H}_{0}$ diterima \\
3 & $\mu_{12}=\mu_{13}$ & 9,6220 & 15,784 & $\mathrm{H}_{0}$ diterima \\
\hline 4 & $\mu_{21}=\mu_{22}$ & 6,220 & 15,784 & $\mathrm{H}_{0}$ diterima \\
5 & $\mu_{21}=\mu_{23}$ & 20,4137 & 15,784 & $\mathrm{H}_{0}$ ditolak \\
6 & $\mu_{22}=\mu_{23}$ & 7,0484 & 15,784 & $\mathrm{H}_{0}$ diterima \\
\hline 7 & $\mu_{31}=\mu_{32}$ & 7,0868 & 15,784 & $\mathrm{H}_{0}$ diterima \\
8 & $\mu_{31}=\mu_{33}$ & 3,1545 & 15,784 & $\mathrm{H}_{0}$ diterima \\
9 & $\mu_{32}=\mu_{33}$ & 0,6720 & 15,784 & $\mathrm{H}_{0}$ diterima \\
\hline 10 & $\mu_{11}=\mu_{21}$ & 0,7686 & 15,784 & $\mathrm{H}_{0}$ diterima
\end{tabular}




\begin{tabular}{rlrll}
11 & $\mu_{11}=\mu_{31}$ & 2,6930 & 15,784 & $\mathrm{H}_{0}$ diterima \\
12 & $\mu_{21}=\mu_{31}$ & 5,9271 & 15,784 & $\mathrm{H}_{0}$ diterima \\
\hline 13 & $\mu_{12}=\mu_{22}$ & 1,6776 & 15,784 & $\mathrm{H}_{0}$ diterima \\
14 & $\mu_{12}=\mu_{32}$ & 16,5844 & 15,784 & $\mathrm{H}_{0}$ ditolak \\
15 & $\mu_{22}=\mu_{32}$ & 8,9484 & 15,784 & $\mathrm{H}_{0}$ diterima \\
\hline 16 & $\mu_{13}=\mu_{23}$ & 0,3332 & 15,784 & $\mathrm{H}_{0}$ diterima \\
17 & $\mu_{13}=\mu_{33}$ & 0,0027 & 15,784 & $\mathrm{H}_{0}$ diterima \\
18 & $\mu_{23}=\mu_{33}$ & 0,4077 & 15,784 & $\mathrm{H}_{0}$ diterima
\end{tabular}

Berdasarkan Tabel 5 di atas dapat disimpulkan bahwa:

Pada penggunaan model pembelajaran TAI dan pembelajaran langsung, siswa dengan kemandirian belajar tinggi mempunyai prestasi belajar matematika yang sama dengan kemandirian belajar sedang dan rendah. Hasil ini tidak sesuai dengan hipotesis penelitian. Hal ini disebabkan ternyata pada pembelajaran TAI, setiap siswa dituntut untuk dapat menyelesaikan tugasnya dengan benar. Akibatnya setiap siswa bersemangat dan aktif dalam pembelajaran. Hasil ini sama dengan hasil penelitian Dhiya Ayu Tsamrotul Ihtiari (2013) yang menyatakan bahwa prestasi belajar matematika siswa dengan kemandirian tinggi sama baiknya dengan kemandirian belajar siswa dengan kemandirian belajar sedang dan Umi Supraptinah (2015) memberikan hasil bahwa prestasi belajar matematika siswa dengan kemandirian belajar sedang sama baiknya dengan prestasi belajar matematika siswa dengan kemandirian rendah.

Pada model pembelajaran GI, siswa dengan kemandirian belajar tinggi mempunyai prestasi belajar matematika yang sama dengan kemandirian belajar sedang, siswa dengan kemandirian belajar sedang mempunyai prestasi belajar matematika yang sama dengan kemandirian belajar rendah, dan siswa dengan kemandirian belajar tinggi mempunyai prestasi belajar matematika yang lebih baik daripada kemandirian belajar rendah. Selanjutnya pada penggunaan model pembelajaran langsung, siswa dengan kemandirian belajar tinggi mempunyai prestasi belajar matematika yang sama dengan kemandirian belajar sedang dan rendah. Hasil ini tidak sesuai dengan hipotesis penelitian. Hal ini disebabkan pembelajaran langsung tidak meningkatkan semangat belajar siswa sehingga siswa dengan kemandirian tiggi dan edang memiliki prestasi yang sama dengan siswa dengan kemandirian rendah.

Siswa dengan kemandirian belajar tinggi, model pembelajaran TAI, GI, dan pembelajaran langsung menghasilkan prestasi belajar matematika yang sama. Hal ini sejalan dengan penelitian Ganjar Susilo (2013) yang menyatakan bahwa tidak terdapat perbedaan prestasi belajar matematika siswa dengan kemandirian tinggi antar model 
pembelajaran yang digunakan. Pada siswa dengan kemandirian belajar sedang, model pembelajaran kooperatif tipe TAI menghasilkan prestasi belajar matematika yang sama dengan model pembelajaran kooperatif tipe GI, hal ini terjadi karena kapasitas siswa dengan kemandirian belajar sedang masih membutuhkan bimbingan yang cukup dari guru.

Pada siswa dengan kemandirian belajar rendah, model pembelajaran kooperatif tipe TAI, GI, dan model pembelajaran langsung menghasilkan prestasi belajar matematika yang sama. Hasil penelitian ini sesuai dengan penelitian yang dilakukan oleh Umi Supraptinah (2015) yang menyimpulkan bahwa tidak ada perbedaan prestasi belajar matematika yang signifikan dari siswa dengan kemandirian belajar rendah antar model pembelajaran yang digunakan.

\section{SIMPULAN DAN SARAN}

Berdasarkan hasil analisis data dapat disimpulkan sebagai berikut. (1) Model pembelajaran kooperatif tipe TAI memberikan prestasi belajar yang sama baik dengan model pembelajaran kooperatif tipe GI. Model pembelajaran kooperatif tipe TAI dan GI memberikan prestasi belajar yang lebih baik daripada pembelajaran langsung. (2) Siswa dengan kemandirian tinggi memiliki prestasi belajar matematika yang lebih baik daripada siswa dengan kemandirian belajar sedang dan rendah. Siswa dengan kemandirian belajar sedang memiliki prestasi belajar yang lebih baik dari pada siswa dengan kemandirian belajar rendah. (3) Pada model pembelajaran kooperatif tipe TAI, siswa dengan kemandirian belajar tinggi, sedang, dan rendah memiliki prestasi belajar yang sama. Pada model pembelajaran kooperatif tipe GI, siswa dengan kemandirian belajar tinggi memiliki prestasi belajar matematika yang lebih baik daripada siswa dengan kemandirian belajar rendah. Siswa dengan kemandirian belajar tinggi memiliki prestasi belajar matematika yang sama baik dengan siswa dengan kemandirian belajar sedang, dan siswa dengan kemandirian belajar sedang memiliki prestasi belajar yang sama dengan siswa dengan kemandirian rendah. Pada model pembelajaran langsung, siswa dengan kemandirian belajar tinggi, sedang, dan rendah memiliki prestasi belajar matematika yang sama. (4) Pada kategori kemandirian belajar tinggi, model pembelajaran TAI, GI, dan pembelajaran langsung memberikan prestasi belajar matematika yang sama. Pada kategori kemandirian sedang, model pembelajaran TAI memberikan prestasi belajar yang lebih baik daripada model pembelajaran langsung, model pembelajaran TAI memberikan prestasi yang sama baik dengan model pembelajaran GI, model pembelajaran GI memberikan prestasi belajar yang sama baik dengan model pembelajaran langsung. Pada 
kategori kemandirian belajar rendah, model pembelajaran TAI, GI, dan pembelajaran langsung memberikan prestasi belajar matematika yang sama.

Berdasarkan simpulan penelitian, disarankan kepada guru untuk menerapkan dapat pembelajaran kooperatif tipe TAI dan GI untuk dapat meningkatkan pestasi belajar matematika siswa khususnya pada materi persamaan garis lurus. Selanjutnya guru disarankan untuk memperhatikan kategori kemandirian belajar siswa dalam merancang pembelajaran sehingga dapat menghasilkan prestasi belajar yang optimal.

\section{DAFTAR PUSTAKA}

Awovala, AOA. and Nneji, LM. 2012. "Achivement in Cooperative versus Individualistic Goal-Structured junior Secondary School Mathematics Classroom in Nigeria". Internasional Journal of Mathematics Trends and Tachnology. 3(1), 7-12.

Awovala, AOA., Arigbabu, AA., Awovala, AA. 2013. "Effect of Framing and Team Assisted Individualised Instruction strategies on Senior Secondary School Student's Attitude Toward Mathematics". Acta Didacta Napocensia. 6(1), 1-22.

Dhiya Ayu Tsamrotul Ihtiari. 2013. Eksperimentasi Model Pembelajaran Kooperatif Tipe Think Pair Share (TPS) dan Numbered Heads Together (NHT) dengan Pendekatan Kontekstual pada Materi Segitiga dan Segiempat ditinjau dari Kemandirian Balajar Matematika Siswa SMP Negeri se-Kabupaten Kebumen. Tesis. Surakarta: UNS.

Ganjar Susilo. 2013. Eksperimentasi Model Pembelajaran Inkuiri dengan Pendekatan Kontekstual dan Model Pembelajaran Kooperatif Tipe Students Teams Achievement Division (STAD) dengan Pendekatan Kontekstual pada Materi Kubus dan Balok ditinjau dari Kemandirian Belajar Siswa SMP Negeri di Kabupaten Purworejo. Tesis. Surakarta: UNS.

Jebson, SR. 2012. "Impact of Cooperative Learning Approach on Senior Secondary School Students Performance in Mathematics". Ife PsychologIA. 20(2), 107-112.

Laila Fitriana. 2010. Pengaruh Model Pembelajaran Cooperative Tipe Group Investigation (GI) dan STAD Terhadap Prestasi Belajar Matematika Ditinjau dari Kemandirian Belajar Siswa. Tesis Pendidikan Matematika. Surakarta: UNS.

Mitchell, MG. 2008. "Group Investigation as a Cooperative Learning Strategy: An Integrated Analysis of Literature". The Alberta Journal of Educational Research. 54(4), 388-395.

Purna Bayu Nugroho. 2014. Eksperimentasi Model Pembelajaran Missouri Mathematics Project (MMP) dan Model Pembelajaran Student Teams Achievement Division (STAD) disertai Assessment for Learning melalui Teman Sejawat ditinjau dari Kemandirian Belajar Siswa Kelas X SMA Sekabupaten Bantul. Tesis. Surakarta: UNS.

Slavin, RE. 2005. Cooperative Learning: Teori, Riset, dan Praktik. Bandung: Nusa Media. 2008. Psikologi Pendidikan Teori dan Praktik. Jakarta: PT Indeks. 
Triana Harmini. 2014. Eksperimentasi Pembelajaran Matematika Menggunakan Pembelajaran Kooperatif Tipe Team Assisted Individualization Dan Tipe Group Investigation Pada Materi Persamaan Dan Pertidaksamaan Kuadrat Ditinjau Dari Gaya Belajar Kolb Pada Siswa SMA Negeri Kelas X Di Kabupaten Ponorogo.Tesis. Surakarta: UNS.

Torrano and Carmen. 2004. Self-Regulated Learning: Current and Future Directions. Electronic Journal of Research in Educational Psychology. 2(1). 1-34.

Umi Supraptinah. 2015. Eksperimentasi Model Pembelajaran Discovery Learning, Problem Based Learning, dan Think-Talk-Write dengan Pendekatan Saintifik terhadap Kemampuan Pemecahan Masalah Matematika Materi Lingkaran ditinjau dari Kemandirian Belajar Siswa Kelas VIII SMP Negeri se-Kabupaten Sragen Tahun Pelajaran 2014/2015. Tesis. Surakarta: UNS. 